\title{
Evaluation of the Chemical Composition of Different Non-Woody Plant Fibers Used for Pulp and Paper Manufacturing
}

\author{
Gisela Marques*, Jorge Rencoret, Ana Gutiérrez and José C. del Río
}

Instituto de Recursos Naturales y Agrobiología de Sevilla, CSIC, P.O. Box 1052, 41080- Seville, Spain

\begin{abstract}
The chemical composition of several non-woody plant fibers (bast fibers from flax, hemp, kenaf, jute; leaf fibers from sisal, abaca and curaua; and giant reed), which are used as raw materials for pulp and papermaking, has been evaluated. Particular attention was paid to the composition of the lipophilic compounds and the structure of the lignin polymer since they are important components of the fiber that strongly influence the pulping and bleaching performances.
\end{abstract}

Keywords: Non-woody fibers, flax, hemp, kenaf, jute, sisal, abaca, giant reed, paper pulp, lipophilic extractives, lignin.

\section{INTRODUCTION}

An alternative to woody raw materials for pulp and paper production in developing countries is the use of non-woody fibers from field crops and agricultural residues. In developed countries, non-woody fibers are mainly used for the production of specialty papers, i.e., tea bags, filter papers, bank notes, etc. On the other hand, there is a growing need within Europe to consider alternative agricultural strategies that move an agricultural industry purely focused on food production to one that also supplies the needs of other industrial sectors, such as paper and textiles. Non-wood fibers, therefore, could become important raw materials in this transformation [1-3]. The main sources of non-woody raw materials are agricultural residues from monocotyledons, including cereal straw and bagasse, or plants grown specifically for the fiber, such as bamboo, reeds, and some other grass plants such as flax, hemp, kenaf, jute, sisal, or abaca. Non-woody plants offer several advantages including short growth cycles, moderate irrigation requirements and low lignin content, which in principle would result in reduced energy and chemicals consumption during pulping [4].

Plant fibers are constituted by three structural polymers (the polysaccharides cellulose, and hemicelluloses and the aromatic polymer lignin) as well as by some minor nonstructural components (i.e. proteins, extractives, minerals). Pulping and bleaching performances are highly dependent on the relative content, structure and reactivity of the plant components. In particular, the lignin content and its composition in terms of $p$-hydroxyphenyl $(\mathrm{H})$, guaiacyl $(\mathrm{G})$ and syringyl (S) moieties and the different inter-unit linkages are important factors in pulp production affecting the delignification rate. It has been shown that higher S/G ratios in woods implied higher delignification rates, less alkali consumption and therefore higher pulp yield [5]. On the other

*Address correspondence to this author at the Instituto de Recursos Naturales y Agrobiología de Sevilla, CSIC, P.O. Box 1052, 41080- Seville, Spain; Tel: +34 95 4624711; Fax: +34 95 4624002;

E-mail: gisela@irnase.csic.es hand, among the non-structural components, lipophilic extractives present special relevance due to their high impact in paper pulp manufacturing [6]. Lipophilic extractives include different classes of compounds (i.e. alkanes, fatty alcohols, fatty acids, free and conjugated sterols, terpenoids, triglycerides and waxes), which have different behavior during pulping and bleaching [6-8]. These lipophilic compounds, even when present in low amounts in the raw material, may play an important role during the industrial wood processing for pulp and paper production since they are at the origin of the so-called pitch deposits. Pitch deposition is a serious problem in the pulp and paper industry being responsible for reduced production levels, higher equipment maintenance costs, higher operating costs, and an increased incidence of defects in the finished products, which reduces quality and benefits [6].

In order to maximize the exploitation of non-woody plant fibers for paper pulp production, a more complete understanding of its chemistry is required. Most studies have been devoted to the chemical characterization of woody materials, while studies on non-woody fibers have been comparatively scarce. In this context, the main objective of this work is to revise and evaluate the chemical composition of different non-woody plant fibers used for pulp and papermaking, that will help improving the industrial processes in which they are used as raw materials.

\section{ANALYTICAL METHODOLOGIES}

\subsection{Samples}

The samples selected for this study were bast fibers from flax (Linum usitatissimum), hemp (Cannabis sativa), kenaf (Hibiscus cannabinus) and jute (Corchorus capsularis); leaf fibers from sisal (Agave sisalana), abaca (Musa textilis) and curaua (Ananas erectifolius); as well as giant reed (Arundo donax).

\subsection{Chemical Analyses}

For hemicellulose and Klason lignin content estimation, milled samples were extracted with acetone in a Soxhlet ap- 
paratus for $8 \mathrm{~h}$ and subsequently extracted with hot water $(3 \mathrm{~h}$ at $100^{\circ} \mathrm{C}$ ). The acetone extracts were evaporated to dryness and resuspended in chloroform for chromatographic analysis of the lipophilic fraction. Klason lignin was estimated as the residue after sulfuric acid hydrolysis of the pre-extracted material. The acid-soluble lignin was determined, after filtering off the insoluble lignin, by spectrophotometric determination at $205 \mathrm{~nm}$ wavelength. Neutral sugars from polysaccharide hydrolysis were analyzed as alditol acetates by GC according to Tappi rules T222 om-88 and T249 om85, respectively [9]. Ash content was estimated as the residue after $6 \mathrm{~h}$ at $575^{\circ} \mathrm{C}$.

\subsection{Analysis of Lipids}

The broad range of molecular masses of lipophilic extractives and their structural diversity represent two important difficulties for their chemical analysis. Hightemperature, short-length $(5 \mathrm{~m})$ capillary columns with thin films were used for the rapid identification and quantification of lipophilic wood extractives with no prior derivatization nor fractionation [10], resulting in an optimal analysis of high-molecular-weight lipids such as waxes, sterol esters, and triglycerides. This method enables elution and separation of compounds with a wide range of molecular weights (from fatty and resin acids to sterol esters and triglycerides) in the same chromatographic analysis. For GC-MS, medium-length high-temperature capillary columns $(12 \mathrm{~m})$ were used [10]. When a more accurate characterization of some compounds was required, the extracts were fractionated by solid-phase extraction (SPE) procedures $[10,11]$.

\subsection{Analysis of Lignin}

Pyrolysis coupled to gas chromatography/mass spectrometry (Py-GC/MS) was used for the "in situ" analysis of the chemical composition of the lignin, in terms of their $\mathrm{H}: \mathrm{G}: \mathrm{S}$ distribution. Lignin is thermally degraded to produce a mixture of relatively simple phenols, which result from cleavage of ether and certain $\mathrm{C}-\mathrm{C}$ inter-unit linkages. The released methoxylated phenols retain the substitution patterns of the different lignin monomers, and it is thus possible to identify components from the $p$-hydroxyphenylpropanoid $(\mathrm{H})$, guaiacylpropanoid $(\mathrm{G})$ and syringylpropanoid $(\mathrm{S})$ lignin units $[5,12,13]$. For a more detailed structural study, the milled wood lignins were isolated according to a known procedure [14] and analyzed by bidimensional nuclear magnetic resonance (2D-NMR). 2D-NMR can provide information of the structure of the whole macromolecule and is a powerful tool for lignin structural elucidation since signals overlapping in the ${ }^{1} \mathrm{H}$ and ${ }^{13} \mathrm{C}$ NMR spectra are resolved revealing both the aromatic units and the different interunit linkages present in lignin [15-18].

\section{CHARACTERIZATION OF THE SELECTED NON- WOODY PLANT FIBERS}

\subsection{Morphological Characteristics of the Fibers}

The morphological characteristics of a fiber, such as fiber length and width, are important parameters in estimating pulp qualities. Fiber length is the most important physical property for pulping as it generally influences the tearing strength of paper. Greater the fiber length, higher will be the tearing resistance of paper. On the other hand, longer fibers tend to give a more open and less uniform sheet structure. Table 1 shows the morphological characteristics of the nonwoody fibers used for this study [19]. An important feature of non-wood fibers is the wide variability among the lengths of the fibers of different species. Some of these fibers have short lengths (i.e. giant reed, with only $1180 \mu \mathrm{m}$ fiber length), similar to the short fibers of hardwoods, while others, and particularly flax and hemp bast fibers, present remarkably high lengths (up to $28000 \mu \mathrm{m}$ fiber length).

Among the studied fibers, flax and hemp pulps have traditionally been used as the primary furnish for cigarette paper (burning tube), where strength, opacity and control of air permeability are required. Banknote paper often incorporates flax or hemp to enhance general strength characteristics. Jute pulp is used for high porosity papers. Its fiber length plus low diameter makes it very suitable for finishing paper purposes. Sisal and abaca pulps have an unusually high tearing resistance and high porosity and are well suited for the production of papers where high strength and high porosity are required.

\subsection{Raw Chemical Composition of the Fibers}

The chemical composition of the main constituents of the selected non-woody fibers is shown in Table 2. In general, they are characterized by a high polysaccharide content and low contents of lignin, lipids and ash [20-22]. Giant reed presents the lowest holocellulose content and the higher content of lignin, which makes it less interesting for pulp and papermaking. The low lignin content of the rest of the fibers, with a lignin content as low as $2.9 \%$ in flax, is in principle advantageous for pulping. Moreover, the acetone extractives content is also low, and usually less than $2 \%$, except for curaua fibers $(5.3 \%$ of total fiber weight). However, most of the acetone extracts in curaua corresponds to polar compounds, while only $1.3 \%$ corresponds to lipophilic compounds, which were estimated by redissolving the acetone extracts in chloroform. Thus, in general, the lipophilic content of the selected non-woody fibers ranges from 0.5 to $1.3 \%$. Finally, the ash content for all the selected fibers was low in comparison to other raw materials used for pulp and papermaking, as the cereal straws, with an ash content generally higher than $15 \%$ [1]. Therefore, according to their chemical composition, most of these fibers seem suitable raw materials for pulp and papermaking.

\subsection{Carbohydrate Composition of the Fibers}

The results of the analyses of neutral sugars of the nonwoody fibers selected for this study are reflected in Table $\mathbf{3}$. The hemicelluloses fraction of the bast fibers presents a higher variability than those of the leaf fibers. Thus, hemicelluloses from flax and hemp are mainly constituted by mannose followed by galactose, while the hemicelluloses from kenaf and jute are predominantly constituted by xylose. On the other hand, all the leaf fibers (sisal, abaca and curaua) show a predominance of xylose. Finally, giant reed presents a strikingly high content of xylose, that amounts up to $39.2 \%$ of the total neutral sugars.

\subsection{Lipid Composition of the Fibers}

As shown in Table 2, all the studied fibers present low extractives contents. However, due to the wide structural 
Table 1. Morphological Characteristics (Length and Width) of the Selected Fibers [19]

\begin{tabular}{|c|c|c|c|}
\hline Fiber Source & Length $(\mu \mathrm{m})$ & Width $(\mu \mathrm{m})$ & $\mathrm{L} / \mathrm{W}$ ratio \\
\hline \multicolumn{4}{|l|}{ Bast fibers } \\
\hline hemp & 20000 & 22 & 1000:1 \\
\hline kenaf & 2740 & 20 & $135: 1$ \\
\hline \multicolumn{4}{|l|}{ Leaf fibers } \\
\hline sisal & 3030 & 17 & 180:1 \\
\hline abaca & 6000 & 20 & $300: 1$ \\
\hline curaua & n.a. & n.a. & n.a. \\
\hline giant reed & 1180 & 15 & $78: 1$ \\
\hline \multicolumn{4}{|c|}{ Woods for comparison } \\
\hline softwoods & 3000 & 30 & 100:1 \\
\hline hardwoods & 1250 & 25 & $50: 1$ \\
\hline
\end{tabular}

n.a. not available

Table 2. Composition of the Main Constituents of the Selected Fibers (\% of Dry Matter) [20-22]

\begin{tabular}{|c|c|c|c|c|c|c|}
\hline & Ash & $\begin{array}{c}\text { Acetone } \\
\text { Extractives }\end{array}$ & Water-Solubles & Klason Lignin & $\begin{array}{c}\text { Acid-Soluble } \\
\text { Lignin }\end{array}$ & Holocellulose \\
\hline \multicolumn{7}{|l|}{ Bast fibers } \\
\hline flax & 1.5 & 0.7 & 1.3 & 2.9 & 1.6 & 92.0 \\
\hline hemp & 2.0 & 0.5 & 1.2 & 4.6 & 1.5 & 90.3 \\
\hline \multicolumn{7}{|l|}{ Leaf fibers } \\
\hline sisal & 1.0 & 0.7 & 2.3 & 5.9 & 3.0 & 85.0 \\
\hline abaca & 0.9 & 0.5 & 1.7 & 7.7 & 1.4 & 85.6 \\
\hline \multicolumn{7}{|l|}{ Reeds } \\
\hline giant reed & 4.2 & 1.6 & 8.5 & 24.7 & n.d. & 49.8 \\
\hline
\end{tabular}

heterogeneity of the compounds that may occur and their different behavior during pulping, the knowledge of the chemical nature of these components, especially the lipophilic compounds, is important in order to predict and control the eventual pitch problems that may occur during pulp- ing and bleaching and to establish appropriate methods and strategies for their control.

The composition of the lipids present in the different fibers was studied by GC and GC-MS and is shown in Table 4. The main lipid classes found in the non-woody fibers are 
Table 3. Composition of Neutral Monosaccharides (as Percentage of Total Neutral Carbohydrates) [20-22]

\begin{tabular}{|c|c|c|c|c|c|c|}
\hline & Rhamnose & Arabinose & Xylose & Mannose & Galactose & Glucose \\
\hline \multicolumn{7}{|l|}{ Bast fibers } \\
\hline flax & 0.4 & 0.9 & 1.1 & 8.8 & 3.5 & 85.3 \\
\hline hemp & 0.4 & 0.6 & 1.0 & 9.9 & 1.6 & 86.4 \\
\hline kenaf & 0.5 & 2.1 & 10.5 & 4.9 & 0.5 & 81.5 \\
\hline jute & 0.5 & 1.5 & 7.9 & 4.2 & 0.5 & 85.4 \\
\hline \multicolumn{7}{|l|}{ Leaf fibers } \\
\hline sisal & 0.3 & 1.9 & 12.0 & 3.6 & 0.6 & 81.7 \\
\hline abaca & 0.3 & 1.6 & 7.5 & 3.5 & 0.3 & 86.9 \\
\hline curaua & 0.0 & 2.7 & 8.0 & 3.5 & 0.2 & 85.6 \\
\hline \multicolumn{7}{|l|}{ Reeds } \\
\hline giant reed & 0.0 & 3.4 & 39.2 & 0.3 & 0.8 & 56.3 \\
\hline
\end{tabular}

Table 4. Composition of Lipophilic Extractives (mg/100g) in the Different fibers [8, 22-26]

\begin{tabular}{|c|c|c|c|c|c|c|c|c|}
\hline & \multicolumn{4}{|c|}{ Bast fibers } & \multicolumn{3}{|c|}{ Leaf fibers } & \multirow{2}{*}{$\begin{array}{c}\text { Reeds } \\
\text { giant reed }\end{array}$} \\
\hline & flax & hemp & kenaf & jute & sisal & abaca & curaua & \\
\hline$n$-alkanes (A) & 27 & 43 & 27 & 5 & 15 & - & - & 8 \\
\hline fatty alcohols (B) & 220 & 2 & 13 & 13 & 8 & $<1$ & 55 & 19 \\
\hline$n$-aldehydes $(\mathbf{C})$ & 371 & 25 & 1 & - & 1 & - & - & 8 \\
\hline fatty acids (D) & 552 & 78 & 33 & 13 & 11 & 9 & 81 & 114 \\
\hline$\omega$-hydroxyfatty acids $(\mathbf{E})$ & - & - & - & 3 & 6 & 1 & 142 & - \\
\hline$\alpha$-hydroxyfatty acids $(\mathbf{F})$ & 11 & 9 & - & 10 & 7 & 1 & 23 & - \\
\hline free sterols/triterpenols (G) & 92 & 36 & 5 & 4 & 20 & 25 & 62 & 53 \\
\hline sterol/triterpenol esters $(\mathbf{H})$ & 6 & 7 & 1 & - & $<1$ & 1 & 9 & 7 \\
\hline sterol glycosides (I) & 5 & 13 & $<1$ & 1 & 2 & 2 & 27 & 15 \\
\hline steroid hydrocarbons $(\mathbf{J})$ & 14 & 30 & 2 & 2 & 14 & 3 & 12 & 13 \\
\hline steroid/triterpenoid ketones $(\mathbf{K})$ & 33 & 27 & 4 & 3 & 3 & 4 & 6 & 4 \\
\hline$n$-alkyl ferulates (M) & - & - & - & - & 6 & 3 & - & - \\
\hline ester waxes* $(\mathbf{L}, \mathbf{N}, \mathbf{O}, \mathbf{P})$ & 284 & 17 & 30 & 20 & 8 & 7 & 222 & 42 \\
\hline
\end{tabular}




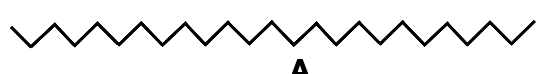

A

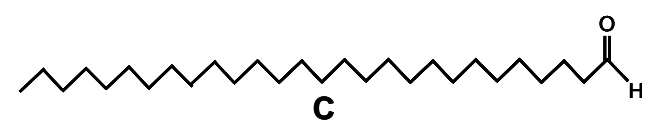

C<smiles>O=C(O)CCCCCCCCCCCCCCCCCCCCCCCCCO</smiles>

E<smiles>CCCCCCCCCCCCCCCCCCCCCCC(O)C(=O)O</smiles><smiles>CCC(CCC(C)C1CCC2C3CC=C4CC(O)CCC4(C)C3CCC12C)C(C)C</smiles><smiles>CCCCCCCCCCCCCCCCCCC(=O)O</smiles>

D<smiles>CCCCC/C=C/C=C/CCCCCCC(=O)OC1CCC2(C)C(=CCC3C2CCC2(C)C(C(C)CCC(CC)C(C)C)CCC32)C1</smiles>

H

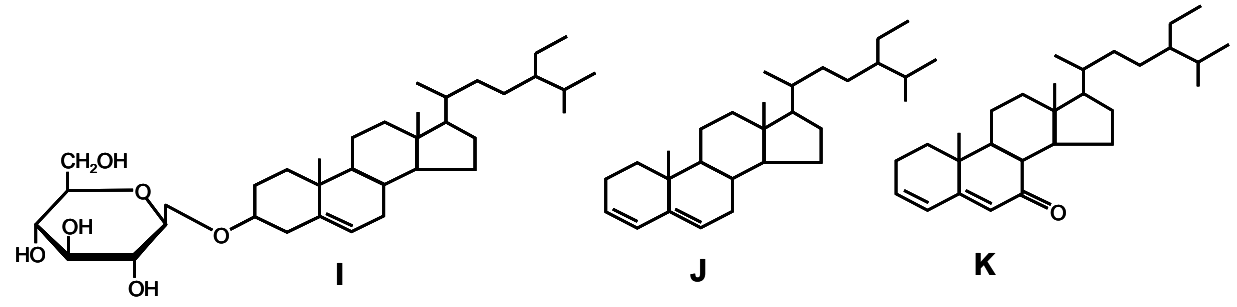<smiles>CCCCCCCCCCCCCCCCCCCCCCCCCCCCCCCCOC(=O)CCCCCCCCCCCCCC</smiles>

$\mathbf{L}$<smiles>CCCCCCCCCCCCCCCCCCCCCCCCOC(=O)/C=C/c1ccc(O)c(OC)c1</smiles><smiles>CCCCCCCCCCCCCCCCCCCCCCOC(=O)CCCCCCCCCCCCCCCCO</smiles><smiles>O=C(O)OCC(O)COC(=O)CCCCCCCCCCCCCCCCCCCCCCCO</smiles>

Fig. (1). Structures of compounds representing the main classes of lipophilic extractives found in the different fibers selected. : A, pentacosane; B, docosanol; C, octacosanal; D, palmitic acid; E, 26-hydroxyhexacosanoic acid; F, 2-hydroxytetracosanoic acid; G, sitosterol; H, sitosteryl linoleate; I, sitosteryl 3ß-D-glucopyranoside; J, stigmasta-3,5-diene; K, stigmasta-3,5-dien-7-one; L, octacosyl hexadecanoate; M, trans-docosanylferulate; N, 1-monodocosanoylglycerol; O, docosanyl, 16-hydroxyhexadecanoate; P, 1-mono(24-hydroxytetracosanoyl)glycerol.

shown in Fig. (1) and consists mainly of alkanes (A), fatty alcohols (B), aldehydes (C), fatty acids (D), sterols (G), sterol esters $(\mathbf{H})$, sterol glycosides $(\mathbf{I})$, steroid hydrocarbons $(\mathbf{J})$, steroid ketones $(\mathbf{K})$ and waxes $(\mathbf{L})$. Other compounds found are alkyl ferulates (M), glycerides (N), $\omega$-hydroxy monoesters (O) and $\omega$-hydroxy acylesters of glycerol $(\mathbf{P})$. The detailed composition of the lipophilic compounds present in these fibers has been addressed [7, 8, 22-27]. The content and composition of the different lipid classes vary considerable among the fibers. In the case of flax bast fibers the predominant lipophilic compounds are fatty acids and aldehydes, accounting for $34 \%$ and $23 \%$ of total extract, respectively, followed by ester waxes (18\%) and fatty alcohols $(13 \%)$. Fatty acids are also the predominant compounds ( $27 \%$ of total extracts) in hemp bast fibers, followed by alkanes $(15 \%)$, free sterols (12\%) and steroid hydrocarbons $(12 \%)$. The predominant lipophilic compounds in kenaf and jute are fatty acids (28 and $35 \%$ respectively), followed by ester waxes (26 and $27 \%$ respectively). Among the selected leaf fibers, free sterols and fatty acids predominate in both 
sisal (20 and 24\%, respectively) and abaca (45 and 19\%, respectively), while in curaua fibers, fatty acids and ester waxes predominate (38 and $34 \%$, respectively), followed by free sterols $(10 \%)$. Finally, in giant reed, the predominant lipophilic compounds are fatty acids $(40 \%)$, followed by free sterols (19\%) and ester waxes (15\%).

Generally, these fibers are pulped by an alkaline process, usually soda/anthraquinone pulping. Therefore, we discuss the behavior and fate of the different fiber components during alkaline cooking. In this context, the lipids present in these fibers can be classified, in general terms, into two principal groups, namely fatty acids (including $\alpha$ - and $\omega$ hydroxyfatty acids) and neutral components, including wax esters, long-chain $n$-fatty alcohols, alkanes, and steroids and triterpenoids. The different lipids classes have different behavior during cooking and bleaching $[7,8]$. The wax esters, which are abundant lipophilic compounds in some of these fibers (i.e. flax and curaua), are hydrolyzed during alkaline cooking and the fatty acids dissolved. At sufficiently high $\mathrm{pH}$ (as in alkaline pulping), the acids dissociate and form fatty acid soaps and can thus dissolve in water to quite a high extent. By contrast, alkanes, fatty alcohols, sterols and triterpenols, steroid hydrocarbons and ketones, and steryl glycosides do not form soluble soaps under the alkaline pulping conditions and therefore survive cooking. These compounds have a very low solubility in water and are difficult to remove, and therefore can be at the origin of pitch deposition. The low amounts of these neutral compounds in most of the fibers, and particularly the low abundances of free and conjugated sterols, which have a high propensity to form pitch deposits [28-30] would point to a low pitch deposition tendency of the lipophilics from these fibers. On the other hand, fatty acid soaps are effective solubilizing agents facilitating the removal from pulp of these sparingly soluble neutral substances. Therefore, the ratio of saponifiables-tounsaponifiables has been suggested to be a better index for predicting pitch problems than the total amount of lipids (Back and Allen, 2000). In fact, the higher abundances of unsaponifiable compounds (neutrals) with respect to the saponifiable ones is the main cause for pitch problems during pulping of some woods, such as aspen or eucalypt [2831]. Fatty alcohols, alkanes and sterols are among the compounds responsible for pitch deposits formed during pulping of nonwoody plants $[8,32]$. In most of the fibers, as in flax, hemp, kenaf or jute fibers, the content of free fatty acids (including $\alpha$ - and $\omega$-hydroxyfatty acids) is high, and therefore the fatty acid soaps formed during alkaline pulping may possess sufficient micellar-forming properties to carry the less polar compounds into solution. However, in other fibers, such as sisal and particularly abaca, the fatty acids amounts up to only $20 \%$ of total lipophilic compounds, and therefore they would be more prone to produce pitch deposition.

\subsection{Lignin Composition of the Fibers}

The lignin content of the non-woody plant fibers selected for this study (estimated as Klason lignin) ranges from 2.9 for flax bast fiber to 24.7 for giant reed (Table 2). The low lignin content of most of the fibers seems to be advantageous for their use in paper pulp manufacturing, as they would require fewer chemicals and less drastic conditions during pulping and bleaching. However, not only the content but the lignin composition also strongly affects delignification rates, chemical consumption and pulp yields $[5,33]$. In general, the efficiency of pulping is directly proportional to the amount of syringyl (S) units in lignin [5]. The $\mathrm{G}$ units have a free C5 position available for carbon-carbon inter-unit bonds, which make them fairly resistant to lignin depolymerization in pulping, while the $\mathrm{S}$ lignin is relatively unbranched and has a lower condensation degree and therefore is easier to delignify. The higher reactivity of the $S$ lignin with respect to the $G$ lignin in alkaline systems is known [34, 35] and, therefore, the lignin $\mathrm{S} / \mathrm{G}$ ratio directly affects the delignification behavior. Higher S/G ratios would imply higher delignification rates, less alkali consumption and, therefore, higher pulp yield $[5,33]$.

The lignin composition of the selected fibers was characterized "in situ" by Py-GC/MS [20-24, 26, 36]. The relative composition of the $\mathrm{H}, \mathrm{G}$ and S-lignin units for the nonwoody fibers studied here is listed in Table 5. A predominance of S- over G-lignin was found in the bast fibers of kenaf [24] and jute [20,36] and in all the leaf fibers of sisal, abaca and curaua [20, 22, 23]. By contrast, the bast fibers from flax and hemp, as well as the giant reed showed a predominance of G-lignin [20, 21, 26]. This is especially evident in the lignin of flax, with an extremely low $S / G$ ratio of 0.1 . The low $\mathrm{S} / \mathrm{G}$ ratio of the lignins from flax and hemp, despite having very low lignin contents (less than 5\% Klason lignin), makes them fairly resistant to alkaline delignification. Also, the high lignin content of giant reed $(24.7 \% \mathrm{Kla}-$ son lignin) together with its low $\mathrm{S} / \mathrm{G}$ ratio of 0.7 makes it especially hard to delignify. By contrast, the rest of the fibers (kenaf, jute, sisal, abaca, curaua) present both high S/G ratios and low lignin contents, which will make them easily delignifiable under alkaline pulping, requiring lower energy and less drastic conditions.

For a more complete structural characterization of the lignins from these non-woody fibers, the milled-wood lignins (MWL) were isolated and analyzed by 2D-NMR spectroscopy [36-38]. Signals from $\mathrm{S}$ and $\mathrm{G}$ lignin units were observed in all spectra, whereas signals for $p$-hydroxyphenyl (H) lignin units could only be detected in the HSQC spectra of flax and hemp lignins, in agreement with the high amounts of these units observed by Py-GC/MS and shown in Table 5. In general, the relative proportions of the different lignin units ( $\mathrm{S} / \mathrm{G}$ ratios in Table 6) are in close agreement with the Py-GC/MS data shown above. In addition, prominent signals corresponding to $p$-coumarate structures were observed in the lignins of abaca and curaua [37]. In these lignins, $p$-coumaric acid has been reported to be esterified to the lignin polymer [23, 37, 39]. The side-chain region of the HSQC spectra gave additional information about the different inter-unit linkages (i.e. $\beta-O-4^{\prime}$ aryl ether, $\beta-\beta^{\prime}$ resinol, $\beta$ $5^{\prime}$ phenylcoumaran, $\beta-1^{\prime} / \alpha-\mathrm{O}-\alpha^{\prime}$ spirodienones, etc) present in the structure of these lignins. The main substructures found in these lignins are depicted in Fig. (2). The relative abundances of the main inter-unit linkages present in the MWL of the non-woody fibers selected for this study are shown in Table 6. $\beta-\mathrm{O}-4^{\prime}$ aryl ether substructures (I) were predominant in all of the lignins. Interestingly, the lignins from kenaf, sisal, abaca and curaua are especially enriched in $\beta-\mathrm{O}-4^{\prime}$ structures (more than $84 \%$ of all side-chains) [37]. Phenylcoumaran ( $\beta-5^{\prime}$ linkages) substructures (II) were observed in most of the fibers, being especially abundant in flax and hemp, but were completely absent in abaca. The 
Table 5. Composition of H, G and S Moieties for All the Raw Materials Studied by Py-GC/MS [20-25, 35]

\begin{tabular}{|c|c|c|c|c|c|c|c|c|}
\hline & flax & hemp & kenaf & jute & sisal & abaca & curaua & $\begin{array}{c}\text { Reeds } \\
\text { giant reed }\end{array}$ \\
\hline$\% \mathrm{G}$ & 40.8 & 53.0 & 15.4 & 32.2 & 18.7 & 13.5 & 29.1 & 44.2 \\
\hline$\% \mathrm{~S}$ & 2.8 & 34.2 & 83.3 & 65.7 & 80.0 & 66.2 & 41.1 & 30.2 \\
\hline
\end{tabular}

Table 6. Structural Characteristics (Relative Abundance of the Main Interunit Linkages as Percentages of Side-Chains Involved, Percentage of $\boldsymbol{\gamma}$-Acylation and S/G Ratio) Observed from the HSQC Spectra of the MWL of Selected Fibers (Curaua, Hemp, Kenaf, Jute, Sisal and Abaca) [35-37]

\begin{tabular}{|c|c|c|c|c|c|c|c|}
\hline & flax & hemp & kenaf & jute & sisal & abaca & curaua \\
\hline$\beta-O-4^{\prime}$ alkyl-aryl units (I, I', I") & 71 & 69 & 84 & 72 & 89 & 94 & 94 \\
\hline Resinols (III) & 13 & 22 & 8 & 16 & 4 & 0 & 0 \\
\hline Spirodienones (IV) & 0 & 0 & 6 & 4 & 5 & 6 & 4 \\
\hline
\end{tabular}

presence of these low amounts of phenylcoumaran substructures was expected due to the low levels of guaiacyl lignin units in these samples. Resinol ( $\beta$ - $\beta^{\prime}$ linkages) substructures (III) were also observed in important amounts in flax, hemp, and jute, and in low amounts in kenaf and sisal, but were completely absent in abaca and curaua lignins. Finally, spirodienone structures (IV) were also present, although in lower amounts in most of the fibers, being absent in flax and hemp. The high abundance of non-condensed linkages in the lignins of kenaf, sisal, abaca and curaua makes them particularly easily to delignify, in contrast to the rest of the lignins, with a high content of condensed linkages, particularly in flax and hemp lignins.

Interestingly, the spectra of some of these lignins (kenaf, sisal, abaca, curaua) revealed the presence of intense signals corresponding to acylated $\gamma$-carbon (Fig. 2, structures $\mathbf{I}^{\prime}$ and I') [37]. An estimation of the percentage of $\gamma$-acylation of the lignin side-chain was calculated by integration of the signals corresponding to the hydroxylated and acylated $\gamma$ carbon (Table 6) and ranged from $4 \%$ in jute lignin to $80 \%$ in abaca lignin. The high level of acylation of the $\gamma$-carbon has been correlated with the high abundances of $\beta-\mathrm{O}-4^{\prime}$ link- ages and the low abundances of the $\beta-\beta^{\prime}$ resinol structures $[37,38]$. The nature of the acyl group esterifying the $\gamma$ carbon was studied by the so-called Derivatization Followed by Reductive Cleavage (DFRC) degradation method [40, 41], which selectively and efficiently cleaves $\alpha$-ether and $\beta$ ether linkages but leaves $\gamma$-esters intact. This method allowed confirming that $p$-coumarate groups are attached at the $\gamma$ carbon of abaca and curaua lignins, and predominantly on syringyl units [37, 41]. In addition, acetate units were also found esterifying the $\gamma$-carbon in the lignins of all the studied fibers, although at different extents. In all cases, acetate and $p$-coumarate groups were found to be preferentially attached to syringyl units [37, 41-43]. It must be noted that, although these ester moieties will, in principle, consume additional alkaline reagents during cooking, it has been shown above that the highly acylated lignins are extremely enriched in easily hydrolysable non-condensed $\beta-\mathrm{O}-4^{\prime}$ linkages, which will be more amenable to delignification.

\section{CONCLUSIONS}

The chemical composition of different non-woody plant fibers used as raw materials for pulp and papermaking has 
<smiles>[CH]C(F)(F)c1cc(OC)c(OC(CO)C(O)c2cc(OC)c(OCC)c(OC)c2)c(OC)c1</smiles>

I

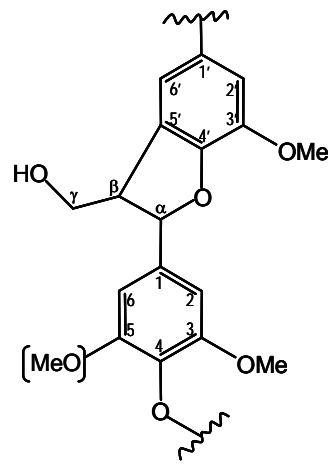

II<smiles>CCOc1c(OC)cc(C(O)C(COC(C)=O)Oc2c(OC)cc(C(C)C)cc2OC)cc1C(C)C</smiles>

I'<smiles>CCCOc1c(OC)cc(C2OCC3C(c4cc(OC)c(OCC)c(OC)c4)OCC23)cc1C(C)C</smiles>

III<smiles>CCOc1c(OC)cc(C(O)C(COC(=O)/C=C/c2ccc(O)cc2)Oc2c(OC)cc(C(C)C)cc2OC)cc1OC</smiles>

["

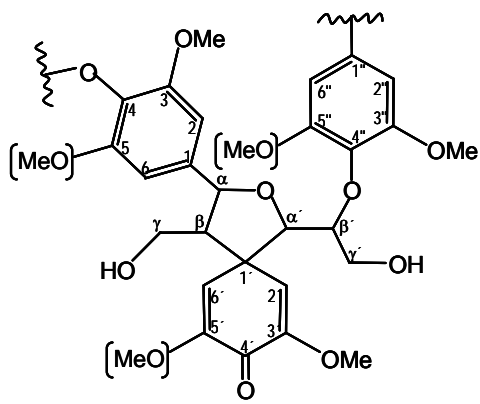

IV

Fig. (2). Main substructures present in the lignins studied here: $\mathbf{I}, \beta-O-4^{\prime}$ linked substructures; $\mathbf{I}^{\prime}, \beta-O-4^{\prime}$ linked substructures with acetylated $\gamma$-carbon; I', $\beta$-O-4' linked substructures; with $p$-coumaroylated $\gamma$-carbon; II, phenylcoumaran structures formed by $\beta-5^{\prime}$ and $\alpha$-O-4' linkages; III, resinol structures formed by $\beta-\beta{ }^{\prime}, \alpha-\mathrm{O}-\gamma^{\prime}$, and $\gamma-\mathrm{O}-\mathrm{R}^{\prime}$ linkages; IV, spirodienone structures formed by $\beta-1$, and $\alpha-\mathrm{O}-\alpha{ }^{\prime}$ linkages.

been summarized, with especial emphasis in the chemistry of lipids and lignin and their fate during alkaline pulping. This study offers valuable information that will lead to a better industrial utilization of these non-woody plant species of high socioeconomic interest.

\section{ACKNOWLEDGEMENTS}

This study has been supported by the Spanish Projects AGL2005-01748 and AGL2008-00709 and the EU BIORENEW project (NMP2-CT-2006-26456). We thank CELESA (Tortosa, Spain) and University of Huelva for providing the samples. G.M. thanks the Spanish Ministry of Education for a FPI fellowship. J.R. thanks the Spanish CSIC for a I3P fellowship.

\section{REFERENCES}

[1] Moore G. Nonwood Fibre Applications in Papermaking, Pira International, Surrey, UK, Leatherhead 1996.

[2] Paavilainen L. European prospects for using nonwood fibres. Pulp Pap Int 1998; 61-86.

[3] Saijonkari-Pahkala K. Non-wood plants as raw materials for pulp and paper. PhD Thesis, University of Helsinki, Finland, 2001; pp. 101.

[4] Hurter RW, Riccio FA. Why CEOS don't want to hear about nonwoods-or should they? In: TAPPI Proceeding, NA Nonwood Fiber Symposium, Atlanta, GA, USA 1998; 1-11.

[5] del Río JC, Gutiérrez A, Hernando M, Landín P, Romero J, Martínez AT. Determining the influence of eucalypt lignin compo- sition in paper pulp yield using Py-GC/MS. J Anal Appl Pyrol 2005; 74: 110-115.

[6] Back EL, Allen LH. Pitch Control, Wood Resin and Deresination, Tappi press, Atlanta, GA., 2000; pp. 392.

[7] Gutiérrez A, del Río JC. Lipids from flax fibers and their fate after alkaline pulping. J Agric Food Chem 2003; 51: 4965-4971.

[8] Marques G, del Río JC, Gutiérrez A. Lipophilic extractives from several nonwoody lignocellulosic crops (flax, hemp, sisal, abaca) and their fate during alkaline pulping and TCF/ECF bleaching. Biores Technol 2010; 101: 260-267.

[9] Technical Association of the Pulp and Paper Industry. Test methods, 1992-1993. TAPPI, Atlanta, Ga. 1993.

[10] Gutiérrez A, del Río JC, González-Vila FJ, Martín F. Analysis of lipophilic extractives from wood and pitch deposits by solid-phase extraction and gas chromatography. J Chromatogr A 1998; 823: 449-455.

[11] Christie WW. In Christie WW, Ed. Solid-phase extraction columns in the analysis of lipids. Advances in Lipid Methodology-One, The Oily Press, Dundee, Scotland 1992; pp. 1-18.

[12] Faix O, Meier D, Fortmann I. Thermal degradation products of wood. A collection of electron of electron-impact (EI) mass spectra of monomeric lignin derived products. Holz Roh- Werkst 1990; 48 (9): $351-354$

[13] Ralph J, Hatfield RD. Pyrolysis-GC/MS characterization of forage materials. J Agric Food Chem 1991; 39(8): 1426-1437.

[14] Björkman A. Studies on finely divided wood. Part I. Extraction of lignin with neutral solvents. Sven Papperstidn 1956; 59: 477-485.

[15] Capanema EA, Balakshin MY, Chen CL, Gratzl JS, Gracz H. Structural analysis of residual and technical lignins by ${ }^{1} \mathrm{H}^{-13} \mathrm{C}$ correlation 2D NMR-spectroscopy. Holzforschung 2001; 55: 302-308.

[16] Capanema EA, Balakshin MY, Kadla JF. Quantitative characterization of a hardwood milled wood lignin by nuclear magnetic resonance spectroscopy. J Agric Food Chem 2005; 53 (25): 9639-9649. 
[17] Liitiä TM, Maunu SL, Hortling B, Toikka M, Kilpeläinen I. Analysis of technical lignins by two- and three-dimensional NMR spectroscopy. J Agric Food Chem 2003; 51 (21): 2136-2143.

[18] Ralph J, Marita JM, Ralph SA, et al. Solution-state NMR of lignin. In: Argyropoulos DS, Ed. Advances in Lignocellulosics Characterization, Tappi Press, Atlanta, GA 1999; 55-108.

[19] García Hortal JA. Fibras Papeleras, Edicions UPC, Barcelona, Spain, 2007; pp. 243.

[20] Rodríguez MI. Caracterización química de plantas hebáceas utilizadas para la fabricación de pasta de papel de alta calidad. PhD Thesis, University of Seville, Spain 2006.

[21] Coelho DS Estudo sistemático da composiçao quimica das fibras de Arundo donax e a sua evoluçao durante a producto de pasta de papel através do processo organosolv. MSc Thesis, University of Aveiro, Portugal, 2006.

[22] Marques G, Gutiérrez A, del Río JC. Chemical characterization of lignin and lipophilic fractions from leaf fibers of curaua (Ananas erectifolius). J Agric Food Chem 2007; 55: 1327-1336.

[23] del Río JC, Gutiérrez A. Chemical composition of abaca (Musa textilis) leaf fibers used for manufacturing of high quality paper pulps. J Agric Food Chem 2006; 54(13): 4600-4610.

[24] Gutiérrez A., Rodríguez IM, del Río JC. Chemical characterization of lignin and lipid fractions in kenaf bast fibers used for manufacturing high-quality papers. J Agric Food Chem 2004; 52: 47644773.

[25] del Río JC, Marques G, Rodríguez IM, Gutiérrez A. Chemical composition of lipophilic extractives from jute (Corchorus capsularis) fibers used for manufacturing of high-quality paper pulps. Ind Crops Prod 2009; 30: 241-249.

[26] Gutiérrez A, Rodríguez IM, del Río JC. Chemical characterization of lignin and lipid fractions in industrial hemp bast fibers used for manufacturing high-quality paper pulps. J Agric Food Chem 2006; 54: $2138-2144$.

[27] Coelho DS, Marques G, Gutiérrez A, Silvestre ARD, del Río JC. Chemical characterization of the lipophilic fraction of Giant reed (Arundo donax) fibres used for pulp and paper manufacturing. Ind Crops Prod 2007; 26: 229-236.

[28] del Río JC, Gutiérrez A, González-Vila FC, Martín F, Romero J. Characterization of organic deposits produced in kraft pulping of Eucalyptus globulus wood. J Chromatogr A 1998; 823: 457-465.

[29] del Río JC, Romero J, Gutiérrez A. Analysis of pitch deposits produced in kraft pulp mills using a totally chlorine free bleaching sequence. J Chromatogr A 2000; 874: 235-245.

[30] Gutiérrez A, del Río JC. Gas chromatography/mass spectrometry demonstration of steryl glycosides in eucalypt wood, kraft pulp and process liquids. Rapid Commun Mass Spectrom 2001; 15: 2515 2520.

[31] Chen T, Wang Z, Zhou Y, Breui, C, Aschim OK, Yee E, Nadeau L. Using solid-phase extraction to assess why aspen causes more pitch problems than softwoods in kraft pulping. Tappi J 1995; 78: 143149.

[32] Gutiérrez A, del Río JC. Chemical characterization of pitch deposits produced in the manufacturing of high-quality paper pulps from hemp fibers. Biores Technol 2005; 96: 1445-1450.

[33] González-Vila FJ, Almendros G, del Río JC, Martín F, Gutiérrez A, Romero J. Ease of delignification assessment of wood from different Eucalyptus species by pyrolysis (TMAH)-GC/MS and CP/MAS ${ }^{13}$ C NMR spectrometry. J Anal Appl Pyrol 1999; 49: 295305.

[34] Chang HM, Sarkanen KV. Species variation in lignin. Effect of species on the rate of Kraft delignification. Tappi press 1973; 56: 132-134.

[35] Tsutsumi Y, Kondo R, Sakai K, Imamura H. The difference of reactivity between syringyl lignin and guaiacyl lignin in alkaline systems. Holzforschung 1995; 49(5): 423-428.

[36] del Río JC, Rencoret J, Marques G, Li J, Gellerstedt G, JiménezBarbero J, Martínez AT, Gutiérrez A. Structural characterization of the lignin from jute (Corchorus capsularis) fibers. J Agric Food Chem 2009; 57: 10271-10281.

[37] del Río JC, Rencoret J, Marques G, et al. Highly acylated (acetylated and/or $p$-coumaroylated) native lignins from diverse herbaceous plants. J Agric Food Chem 2008; 56: 9525-9534.

[38] Martínez AT, Rencoret J, Marques G, et al. Monolignol acylation and lignin structure in some nonwoody plants: A 2D NMR study. Phytochemistry 2008; 69: 2831-2843.

[39] Sun RC, Fang JM, Goodwin A, Lawther JM, Bolton J. Fractionation and characterization of ball-milled and enzyme lignins from abaca fibre. J Sci Food Agric 1999; 79: 1091-1098.

[40] Lu F, Ralph J. Derivatization followed by reductive cleavage (DFRC method), a new method for lignin analysis: protocol for analysis of DFRC monomers. J Agric Food Chem 1997; 45(7): 2590-2592.

[41] del Río JC, Marques G, Rencoret J, Martínez AT, Gutiérrez A. Occurrence of naturally acetylated lignin units. J Agric Food Chem 2007; 55: 5461-5468.

[42] Ralph J, Lu F. The DFRC method for lignin analysis. 6. A simple modification for identifying natural acetates in lignin. J Agric Food Chem 1998; 46: 4616-4619.

[43] Ralph J. An unusual lignin from kenaf. J Nat Prod 1996; 59(4): 341-342.

\section{(C) Marques et al.; Licensee Bentham Open.}

This is an open access article licensed under the terms of the Creative Commons Attribution Non-Commercial License (http://creativecommons.org/licenses/ by-nc/3.0/) which permits unrestricted, non-commercial use, distribution and reproduction in any medium, provided the work is properly cited. 